Jože Krašovec

\title{
Biblična arheološka zbirka, sad Božje milosti
}

\author{
Biblical Archaeological Exhibition, \\ Fruit of God's Grace
}

Poročilo Report (1.25)

UDK UDC: 069.51:903/904(497.4Maribor) DOI: www.doi.org/10.34291/Edinost/74/Krasovec

V četrtek, 4. oktobra 2018, je bila v Sinagogi Maribor odprta biblična arheološka razstava Teološke knjižnice Maribor ob 50. obletnici Enote v Mariboru Teološke fakultete Univerze v Ljubljani z naslovom $O d$ puščave do mize. Ob tej priložnosti sta Center judovske kulturne dediščine Sinagoga Maribor in Teološka fakulteta UL, Enota v Mariboru, izdala katalog razstave. Poročilo o otvoritvi je v reviji Edinost in dialog (73: 277-284) objavil Samo Skralovnik.

Predgovori na začetku kataloga navajajo imena, ki so imela kakšen delež v nastajanju in oblikovanju biblične arheološke zbirke, vendar nikjer ni navedeno, kako je zbirka nastala. Samo Skralovnik, ki je naveden kot avtor razstave, v svojem poročilu v reviji Edinost in dialog poudarja »edinstvenost « biblične arheološke zbirke Teološke knjižnice Maribor, o izvoru pa toliko:

Zbirka predmetov iz Svete dežele izvira z območij današnjega Izraela, Palestine in Egipta in je edinstvena zbirka v Sloveniji. Nekateri muzeji v Sloveniji sicer hranijo posamezne predmete $\mathrm{z}$ Bližnjega vzhoda, ta zbirka pa je edina, ki je v celoti posvečena biblični arheologiji. Sestavljena je bila z mislijo, da bi bila uporabljena kot didaktični pripomoček, ki naj študentom in drugim približa zgodovino Svetega pisma. Zbirka je v zasebni lasti, hrani 
jo Teološka knjižnica Maribor. Predmeti iz zbirke so bili kupljeni v različnih antikvariatih v Jeruzalemu in imajo certifikate, iz katerih je razvidno njihovo poreklo. (277)

V zvezi s katalogom predmetov pa Skralovnik poroča: »Osnovni katalog zbirke je rokopisni popis predmetov, ki ga je v Izraelu pripravil arheolog Jean-Baptiste Humbert na francoski biblični in arheološki šoli École Biblique et Archeologique v Jeruzalemu.» (278)

V Teološki knjižnici Maribor vedo, kako je biblična arheološka zbirka nastala, zato bi bilo logično, da bi bila predstavitev zbirke skladno z etičnim kodeksom in s splošno prakso po svetu celovita. Ker se to ni zgodilo, sem iz strokovnih in moralnih razlogov dolžan, da v vlogi pobudnika in avtorja biblične arheološke zbirke navedeno poročilo dopolnim. Če govorimo o »edinstvenosti« zbirke, naj omenim, da »edinstvenost « te zbirke vidim predvsem v tem, da je sad Božje milosti - kot sploh naše življenje in vse, kar nam je dano.

Nastanek take zbirke originalov iz daljne orientalske dežele v zapletenih političnih razmerah je veliko obsežnejša zgodba, kakor si sploh lahko kdo predstavlja. Zamisel o taki zbirki je bila moja od vsega začetka mojega podiplomskega študija s področja Svetega pisma. Po končani prvi polovici študija na Bibličnem inštitutu v Rimu mi je bila leta 1973 v okviru Nemške škofovske konference dana milost enoletnega študija na École Biblique et Archéologique Française v Jeruzalemu. Zelo pomembno težišče študija na tej šoli je spoznavanje arheoloških najdišč po vsej biblični deželi pod vodstvom profesionalnih arheologov, zato se v enem letu zvrsti veliko potovanj in natančnih pregledov arheoloških najdišč. Arheološke ekspedicije je pogosto vodil arheolog Jean-Baptiste Humbert (dominikanec duhovnik), ki je večinoma vodil arheološka izkopavanja v raznih krajih Bližnjega vzhoda, takrat največ v Jordaniji, zato je bil pogosto za dalj časa odsoten. Priložnostna srečanja pa so vodila do tega, da sva postala prijatelja. Ko sem mu prvič omenil svojo zamisel, da bi postopoma odkupil izvirne arheološke predmete iz celotnega obdobja biblične zgodovine, mi je obljubil pomoč s svetovanjem in navezovanjem stikov z avtoriziranimi trgovinami za področje antične arheologije. 
Avtorizirane trgovine obstajajo na arabskem področju Jeruzalema, a so pod zelo strogo kontrolo države Izrael. Pravilo je, da morajo avtorizirani trgovci vse unikate, ki po kakršnikoli poti pridejo do njih, zadržati za izraelske državne muzeje. Ko se pokaže, da je predmetov istega tipa več, kakor jih država potrebuje za svoje potrebe, lahko višek zaloge prodajo z izdajo certifikata. V zvezi z mojo zamislijo, da bi s pomočjo strokovnih ocen arheologa Humberta začel kupovati arheološke predmete, ki so bili dostopni, je bila glavna težava vprašanje, kako take predmete legalno spraviti preko vseh meja, ki obstajajo med Izraelom in Slovenijo. Rešitev sem našel v zvezi s študijskimi potovanji slovenskih novomašnikov, ki sem jih vodil prvič leta 1973, ko je bil novomašnik pater Silvin Krajnc. On je tisto leto organiziral študijsko potovanje novomašnikov po Sveti deželi. Ker sem bil ravno takrat v Jeruzalemu na izpopolnjevanju, je mene prosil za strokovno vodstvo.

Tisto študijsko potovanje je bilo tako doživeto za vse, da je pater Silvin Krajnc kar vsako leto organiziral dvotedensko študijsko potovanje po Sveti deželi pod mojim vodstvom. Vseh skupin po 50 novomašnikov, drugih duhovnikov in laikov, ki sem jih vodil bolj ali manj vsako leto, je bilo v celoti 25, kar znaša skupno eno celo leto potovanj po bibličnih deželah. Nekateri potniki so bili pripravljeni po en arheološki predmet vključiti v svojo osebno prtljago. Na ta način mi je uspelo v letih pred osamosvojitvijo in v nekaj letih po osamosvojitvi Slovenije s pomočjo arheologa Humberta nabaviti pomembno zbirko izvirnih arheoloških predmetov iz raznih obdobij in z različnih lokacij. Prof. pater Humbert pa je bil še tako prijazen, da je za vsak predmet pripravil tudi strokoven opis glede kraja najdišča, časa nastanka in funkcije predmetov. Vse te usluge je naredil brezplačno. Poleg tega mu je zaradi odličnih stikov z vsemi arheološkimi ustanovami uspelo doseči tudi dostopne cene za same predmete. Za vsak predmet sva od avtoriziranih trgovcev zahtevala uraden certifikat. Za nakup predmetov sem vsako leto pripravil nekaj finančnih sredstev z darovi nekaterih znancev v tujini za moje študijske potrebe, nekaj darov pa so prispevali udeleženci študijskih potovanj, ki so na koncu zbrali nekaj za »honorar«. Vsa ta svoja sredstva sem namenil za nakup navedene zbirke.

Ko je bila zbirka zaključena po osnovnem načrtu, ki mi ga je predlagal pater Humbert, sem se odločil, da celotno zbirko podarim Teološki knjižnici Maribor, ker se je takratni ekonom Mirko Krašovec, ki je bil najprej v letu 1985 zadolžen za gradnjo škofijske avle in nove teološke knjižnice, 
v naslednjih letih vsestransko angažiral tudi za nabavo osnovnega knjižnega fonda, in sicer po seznamu, ki sem mu ga jaz pripravil. Moj predlog je bil, da je treba začeti nabavo vseh temeljnih besedil in dokumentov grško-rimske dobe, zgodnjekrščanske literature, srednjeveških filozofskih in drugih spisov in končno novejšega obdobja. Nekatere zbirke virov so izredno obsežne, zlasti Loeb Classical Library grško-rimskih virov (okoli 600 dvojezičnih knjig), zbirka patrističnih besedil Corpus Christianorum itd., zato to take zbirke izredno drage. Ekonom je v krogu svojih znancev (torej ne iz rednih škofijskih virov) iskal sredstva, jaz pa sem pisal direktorjem svetovnih založb, ki izdajajo take zbirke, da sem jim predstavil naše razmere in jih prosil za maksimalen možen popust. Večina direktorjev je odobrila 50- ali 60-odstotni popust. Tako nam je uspelo nabaviti osnovni fond, brez katerega resno znanstveno delo na področju teologije, religiologije, filozofije itd. ni možno. Glede na to akcijo se mi je zdelo smiselno, da svojo arheološko zbirko podarim novi teološki zbirki v Mariboru.

Z osamosvojitvijo Slovenije so nastopile ugodnejše razmere za delovanje Teološke knjižnice v Mariboru, še zlasti ko je bila Teološka fakulteta sprejeta v okrilje Univerze v Ljubljani. Takoj po osamosvojitvi sem poskusil realizirati še zamisel stalne večje razstave arheoloških predmetov iz bibličnih dežel. Navezal sem stike z oddelkom za starodavnosti izraelskega (Department of Antiquities, direktor Amir Drori) z idejo, da bi morda dosegli dogovor med Izraelom in ustrezno ustanovo v Sloveniji za stalno razstavo pomembnejših predmetov iz obdobij biblične zgodovine. Direktor je bil tej ideji naklonjen in je ponudil možnost, da bi nam Izrael dal nekaj sto predmetov v varstvo za stalno razstavo, kar bi dolgoročno gledano praktično pomenilo v lastništvo. Potem sem v Sloveniji ob sodelovanju s patrom Silvinom Krajncem pridobil firmo, ki je bila pripravljena plačati stroške organizacije prevoza, adaptacije ustrezne manjše dvorane in postavitve razstave. $\mathrm{V}$ upanju proti upanju sem preveril, ali bi bilo mogoče v okviru Teološke fakultete dobiti tak prostor, a se je pokazalo, da to ni bilo realno. Na to idejo pa je ostal lep spomin. 